\title{
Institutional and Symbolic Aspects of Illiberal Politics: The Case of North Macedonia (2006-2017)
}

Borjan Gjuzelov, PhD Candidate, Queen Mary University of London borjan.gjuzelov@gmail.com

Milka Ivanovska Hadjievska, Research Associate, University of Exeter mi269@exeter.ac.uk

\begin{abstract}
The paper discusses the underlying characteristics of Macedonian illiberal politics during the 11-year rule of the centre-right party VMRO-DPMNE (2006-2017) focusing on two aspects: institutional and symbolic. We argue that the unfair political competition was enabled by the weakness of pre-existing institutions and the population's clientelist preferences, which were systematically exploited and expanded by VMRO-DPMNE. Also, we argue that the multiethnic character of the country, the disputed Macedonian national identity and the lack of viable international prospects allowed VMRO-DPMNE to construct a strong nationalist narrative that appealed to voters and further isolated the opposition.
\end{abstract}

Key words: North Macedonia, illiberal politics, VMRO-DPMNE, competitive authoritarianism, case study analysis 


\section{Introduction}

In the period between 2006-2017, North Macedonia, ruled by a coalition government led by the Internal Macedonian Revolutionary Organization - Democratic Party for Macedonian National Unity (VMRO-DPMNE) became an illustrative example of how illiberal politics is made. During this period the country diverged from its democratisation trajectory due to incumbents' active monopolisation of power and abuse of state institutions and resources (Bieber 2018; Crowther 2017). Besides, this undemocratic turn was characterised by strong populist and ethno-nationalist narratives which 'purposefully deepened divisions in the society' (Crowther 2017, 752; Petkovski and Nikolovski 2018) and promoted 'an atmosphere of uncertainty' (Günay and Dzihic 2016, 537).

N. Macedonia was not an isolated example of such developments. In recent years the scholarly attention on hybrid regimes in post-communist countries of both Central East Europe and the South East Europe has significantly gained traction (see Bieber, Solska and Taleski 2018; Greskovits 2015). In the first group of countries the debate is focused on the growing tendencies of democratic deconsolidation, de-democratisation, backsliding, and regression (Bogaards 2018; Claneti, Dawson and Hanley 2018; Bustikova and Guasti 2017) presuming that these countries, as EU member states have already reached some satisfying democratic benchmarks. Regarding the second group of countries the literature is still dealing with the stalled and constrained democratic consolidation (Bieber and Ristic 2012), weak states (Bieber 2011; Kostovicova and Bojicić-Dželilović 2006) and inability to secure functioning rule of law (Dolenec 2013). Despite these differences, countries in both groups face similar 'authoritarian tendencies' that endanger constitutional division of power, political competition and some fundamental civil liberties (Bieber, Solska and Taleski 2018). 
One of the underlying characteristics of most of these hybrid regimes which exist between the poles of democracy and authoritarianism are the actions by governing elites used for monopolisation of power beyond constitutional limits.

Illiberal politics is understood in this issue as a specific set of policies and actions undertaken by governing parties with the aim of creating an uneven playing field to be able to remain in power indefinitely. Whilst the focus on the sum of illiberal policies and actions avoids the complicated task of classifying regime types on the democracy-authoritarianism continuum, it provides a good analytical tool for capturing directions of change - away or towards authoritarianism (Kapidžić, introduction to this issue). Similar approach has been used in the volume by Bieber, Solska and Taleski $(2018,16)$ focusing on 'authoritarian tendencies' as a political development and not an outright shift towards full authoritarianism. Building on this theoretical foundation, we further distinguish between institutional and symbolic elements of illiberal politics.

Under institutional aspects of illiberal politics we understand policies and actions by governing parties involving political abuse of state institutions and resources that generate unfair political competition. This is similar to what Levitsky and Way (2010) define as competitive authoritarianism. They underline the importance of an even playing field for fair contest between political parties as a democratic precondition and consider it skewed when: (1) there is abuse of state institutions for partisan ends; (2) ruling parties are systematically favoured, and (3) the opposition's ability to successfully compete in elections is notably limited. As a consequence, they conceptualise uneven playing field as an outcome of the incumbent's privileged, uneven access to resources, media and law (Levitsky and Way 2010, 10). Taking a process-oriented approach, the institutional illiberal politics of the governing 
elites that we focus on encompass those policies which aim to increase the privileged access to resources, media and law with the aim of creating an uneven playing field. ${ }^{1}$

By symbolic aspects of illiberal politics we understand the policies and actions geared towards the monopolization of public discourse with ethno-nationalist, anti-communist or otherwise divisive discourse in order to legitimise incumbents and discredit political opponents (Bieber and Solska 2018; for similar emphasis on the elite's ability to frame the political debate see Schatz 2009). The distinction between institutional and symbolic elements of illiberal politics is important for two reasons: firstly, the two sets of mechanisms for maintaining power - institutional and symbolic - are related to different enabling circumstances; and secondly, institutional capture and symbolic politics in a given context skew the level playing field in a different way, hence the distinction helps in providing a richer empirical account on the intensity and the interrelatedness of these elements in a given context.

In this paper we argue that the rule of VMRO-DPMNE and their ethnic Albanian coalition partner, the Democratic Union for Integration (DUI) between 2008 and 2017, especially in the second half of this period, is a typical case of illiberal politics (see Petkovski and Nikolovski 2018; Ramet 2017). In accordance with our conceptual distinction we aim to describe the underlying characteristics of the rule of the VMRO-DPMNE-led coalition by focusing on both institutional and symbolic elements and their interrelatedness. Whilst our account is agency-centered and focuses on the set of policies that VMRO-DPMNE actively implemented to skew the level playing field and maintain loyal support base, we recognize the different circumstances which enabled the rise of illiberal politics in the Macedonian

\footnotetext{
${ }^{1}$ With the help of institutional illiberal politics we capture the process of creating privileged access over time. Only when the governing elites are successful in achieving such outcome, we can qualify the political regime as competitive authoritarian.
} 
context. In line with Dolenec (2013), the institutional mechanisms of illiberal politics we focus on in N. Macedonia were enabled by post-communist power mutations manifested through a strong executive, weak institutional check and balances, and clientelist political parties (see also Kapidžić, introduction to this issue). The symbolic illiberal politics has been enabled by the multi-ethnic character of the country (power sharing arrangements) and disputed national identity that culminated with the halt to EU and NATO integration.

To illustrate the usefulness of the conceptual distinction and our main argument we have conducted a case study analysis on illiberal politics in N. Macedonia in the period 2006-2017. The case study is based on media articles, monitoring reports from civil society and international actors and secondary sources (e.g. academic articles including N. Macedonia as a case). ${ }^{2}$ The data from different sources was triangulated and information for which we had at least two independent sources were included in the case study narrative (Hammersley 2008; Yin 2018).

The structure of the paper is as follows: the paper starts with a brief overview of $\mathrm{N}$. Macedonia's general political context and the party-political scene developed since independence. Then the main institutional and symbolic aspects of Macedonian illiberal politics during the rule of VMRO-DPMNE are presented. Finally, in the discussion and conclusion section, we discuss the interrelatedness of institutional and symbolic aspects of illiberal politics and the distinct enabling circumstances behind these tendencies.

\section{Background: The Post-communist Transition during the 1990s}

\footnotetext{
${ }^{2}$ Both authors are native Macedonian speakers and in the past have worked in civil society organisations in $\mathrm{N}$. Macedonia. This gives us the advantage to access documents, local media sources and civil society reports in the original language. To counterbalance potential biases, we rely on peer-reviewed international academic sources which analyse various aspects of Macedonian democratization.
} 
Macedonian independence in 1991 triggered a 'triple transition' (Offe 2004) towards the establishment of new independent state institutions, multi-party democracy and market economy. During the first decade of independence, N. Macedonia faced multiple challenges: a national identity strongly contested by neighbouring Bulgaria and Greece; tensions related to the multi-ethnic composition of the country, with a sizable Albanian minority constituting one quarter of the population (Daskalovski 2004; Crowther 2017, 744); as well as very low levels of economic development and living standards due to the disintegration of the Yugoslav market, regional wars, and the Greek economic embargo in the first half of the 1990s (Boduszyński 2010). In the second half of the 1990s economic development was further constrained by UN sanctions on Yugoslavia and the Kosovo refugee crisis (Boduszyński 2010). These challenges continued to shape the transitional trajectory of $\mathrm{N}$. Macedonia during the 2000s and represent crucial contextual anchors for understanding the failure to consolidate its democracy post-independence, and, specifically, the democratic reversal during VMRO-DPMNE's rule discussed in this paper.

According to Dolenec $(2013,48)$, in post-communist countries dominated by authoritarian parties and undergoing regime change, undemocratic practices from state socialism were not only perpetuated but also expanded with new forms of power abuse. The political parties that defined the new institutional rules during regime change, and led the redistribution and privatization of publicly owned capital, abused this opportunity for amassment of wealth and power (Dolenec 2013, 4). This was the case in N. Macedonia, where the process of democratization during the 1990s was marked by 'strong hold on power of the successor party to the local League of Communists', the Social Democratic Union of Macedonia (SDSM) (Bieber and Ristić 2012, 381). The SDSM government during the 1990s exercised 
control over the media and 'ruled in a competitive authoritarian manner' (Levitsky and Way $2010,125)$.

The development of the party system in Macedonia in the first half of the 1990s thus happened in the context of very low levels of economic viability and high unemployment (Boduszyński 2010) exacerbated by the process of privatization of public companies implemented in 1995/1996 (Bértoa and Taleski 2016). The privatization processes benefited managers of public companies who had close ties with the ruling party SDSM and who were alter seen as the private sponsors of the party (Bértoa and Taleski 2016, 551). These tendencies continued in the later stages of privatization during the first government of VMRO-DPMNE (1998-2002), when businessmen and individuals close to them also benefited from it. This is in line with Boduszyński's $(2010,144)$ observation that the political parties were the 'main site of corruption (...) and used quasi privatization to enrich their members'.

Similarly to other Western Balkan countries, parties' mobilisation capacity and their membership was and still is largely determined by their clientelist potential to redistribute public goods and serve as important informality brokers that provide their supporters with employment opportunities and privileged access to public services and resources (Bieber and Ristić 2012; Günay and Dzihic 2016; Bliznakovski, Gjuzelov and Popovikj 2017). In this context, it is not surprising that the estimated percentage of citizens who are political party members in N. Macedonia is $13 \%$, which is slightly higher than the estimated Western Balkan average of 10\% (Bliznakovski, Gjuzelov and Popovikj 2017) and the Eastern European average of 3\% (van Biezen, Mair and Poguntke 2011). Consequently, once they get in power, political parties tend to address population's clientelist 'shared expectations', and 
thus start to abuse public institutions and resources for party gains (Bliznakovski, Gjuzelov and Popovikj 2017). As a result, incumbent parties capture state institutions through the 'employment of party members in the civil service' and in this way overpower the institutions that are supposed to constrain their behaviour (Bieber and Ristić 2012, 354).

In addition to the dominance of the 'authoritarian party' during regime change, the newly formed state faced challenges to its statehood (Dolenec 2013; Daskalovski 2004). During the first decade of independence, even though interethnic relations posed a 'security concern' (Bértoa and Taleski 2016, 548), Albanian grievances were largely unaddressed (see Daskalovski 2004; Crowther 2017, 745) and an inter-ethnic conflict escalated in 2001 when ethnic Albanian paramilitary groups (National Liberation Army) clashed with the Macedonian army and police. The conflict ended with the signing of the Ohrid Framework Agreement (OFA) under the brokerage of the EU and NATO, which promised an acceleration of the Euro-Atlantic integration of the country (Ilievski 2007; Ilievski and Taleski 2009). The OFA entailed constitutional amendments and the adoption of a consociational model of democracy, characterised by qualified majority procedures in the parliament, decentralisation, equitable representation in the public administration and extended rights for the use of minority languages (Aleksovska 2015, 55; Crowther 2017).

In the years after the inter-ethnic conflict the relations between ethnic Macedonian and Albanian communities remained fragile and were characterised by limited social interaction due to the linguistic barriers and geographical separation (Crowther 2017, 746). The party competition mirrors the 'parallel societies' division, and even before the 2001 conflict, 
governments were formed by the two most successful parties in each ethnic block. ${ }^{3}$ The Macedonian party system is mainly structured around VMRO-DPMNE on the ideological right, and SDSM on the left, and Albanian parties DUI ${ }^{4}$ and $\mathrm{DPA}^{5}$ competing for the votes of ethnic Albanians (Bértoa and Taleski 2016; Crowther 2017). Such ethnicizing of party politics has been identified as a further obstacle to democratic consolidation (Dolenec 2013).

In addition, since independence, Macedonian national identity and language were challenged by neighbouring countries, which incited an atmosphere of external threat to sovereignty. Bulgaria, although it recognized the independence of the country, contested the existence of Macedonian ethnic identity and language, considering the Macedonian language to be a dialect of Bulgarian (Ilievski and Taleski 2009; Crowther 2017). Moreover, the name dispute became a serious obstacle for the integration of N. Macedonia in the EU and NATO (Vangeli 2011). Specifically, in 2008 Greece vetoed N. Macedonia's application to join NATO, whilst in 2009 Greece blocked the start of accession negotiation processes for EU membership. The prospects for joining the EU were further hindered by Bulgaria, which in 2012 supported Greece in delaying the accession negotiations (Ilievski and Taleski 2009; Crowther 2017). Due to the blockade, the EU's leverage to support the democratic consolidation of the country was seriously restrained (Ilievski and Taleski 2009).

Electoral Politics during VMRO-DPMNE's Rule, 2006-2017

\footnotetext{
${ }^{3}$ The only exception to this practice occurred in 2006 when VMRO-DPMNE formed a coalition with the second-highest ranked Albanian party in terms of vote-share Democratic Party of Albanians (DPA). However, this changed following the 2008 snap elections when the 'unlikely' VMRO-DPMNE - DUI coalition was formed which lasted until 2016.

${ }^{4}$ DUI was formed in 2002, emerging from former members of the National Liberation Army.

${ }^{5}$ During the early 1990s the major party representing ethnic Albanians was the Party for Democratic Prosperity (PDP), and later the Democratic Party of Albanians (DPA) (Crowther 2017, 746).
} 
Throughout the period 2006-2017, VMRO-DPMNE enjoyed a continuous electoral legitimisation that helped them expand their political power at all levels and branches of government. After 2008, criticism by both international and domestic actors of abuse of state institutions and resources for party ends was increasing, as well as of their populist and nationalist rhetoric which had polarised society and endangered fragile inter-ethnic relations (Dolenec 2013, 91). However, during their 11-year rule, VMRO-DPMNE has been constantly re-legitimised via nine subsequent electoral wins between 2006 and 2017 in parliamentary, presidential and local elections. Throughout this period, they organised early elections before the end of each of their four-year terms ${ }^{6}$ : four of their parliamentary election victories were victories on early elections. Early elections were justified as necessary due to political disputes with the opposition SDSM or with their coalition partner, DUI, as a pragmatic move to regain new legitimacy and take full advantage of their high political rating. With this practice they kept their electorate continuously mobilised and maximised their political support. Moreover, as the opposition was disorganised and financially weaker than the incumbent coalition, such frequent election cycles have additionally increased the gap between the ruling and opposition parties.

Between 2006 and 2017, although elections were generally considered well-administered, numerous deficiencies were noted, ranging from insufficient separation between state and party structures (particularly in 2011, 2013, 2014) to intimidation of voters and biased and pro-governmental media reporting (see Table 1 for an overview of general conclusions by OSCE/ODIHR Election Observation Mission).

\section{[ADD Table 1. HERE]}

\footnotetext{
${ }^{6}$ This was the case with the early elections in 2008, in 2011 and 2014, while the early elections in 2016 were organised as part of an internationally mediated Przino agreements (elaborated further in the paper).
} 
This constant electoral legitimisation generated a vicious cycle of uneven political competition: on one hand, with continuous and convincing electoral wins the incumbents have expanded their informal power to control and misuse state institutions and resources, while on the other, their control and misuse of state institutions and resources have increased the unfair political competition which helped them continue winning elections. Thus, they became a model example of competitive authoritarianism using a wide variety of practices ranging from misuse of public resources for party gains and abuse of key state institutions such as the Ministry of Interior, the intelligence services and judiciary (Priebe 2015, 2017). As the lines between the three constitutionally divided branches of power were blurred, the executive, directly controlled and micromanaged by top VMRO-DPMNE officials, had excessive control over the parliamentary and judicial branch. This further weakened the already underdeveloped institutional checks and balances system that was overridden anyway by a parallel, informal hierarchy determined and controlled by the party in power.

Simultaneously, the opposition parties, which were successively on the losing side, struggled to convince voters with their political programme and had to use extra-institutional measures such as parliamentary boycotts and civic protests in order to regain political leverage and try to level the political field. As will be elaborated further in the chapter, opposition parties struggled to have their voice heard in the media, nor did they have any real opportunity to institutionally influence or constrain the policies of the incumbent coalition. A good illustration is an incident in 2012, when the SDSM's MPs were physically expelled from the plenary session of the Parliament by security while they were filibustering the procedure for enactment of new annual budget that they characterised as profligate and excessive (Casule 2012). Due to the lack of political dialogue, the opposition boycotted the parliament during periods of 2011, 2013 and 2014 (Marusic 2011, 2013, 2014), whilst mass civic protests were organised in 2015 and 2016 (Marusic 2016a). Civic protests were organised since 2009 by 
independent civil society actors and citizens not allied with the opposition parties (see Petkovski and Nikolovski 2018, 212-214), and they rose in scale in the last years of their rule (2015-2017).

In 2015 a wiretapping scandal revealed by the opposition hit the incumbent coalition. The scandal revealed mass abuse of the state intelligence apparatus (Marusic 2016b; Ramet 2017) and numerous corruption cases which were not properly investigated by the existing anticorruption institutions (Priebe 2015; Keil 2018). As a consequence, in the summer of 2015 two internationally brokered agreements, the "Przino Agreements ${ }^{97}$ were signed by the main incumbent and opposition parties. The agreements envisaged a number of provisions to address the problem of the uneven playing field for fair political competition through the formation of a pre-election interim government and the establishment of a Special Public Prosecutor's Office to investigate the allegations for mass abuses of public office and resources.

In 2017, after the early parliamentary elections in December 2016, in which VMRO-DPMNE won most number of parliamentary seats (51) but failed to form a post-election coalition with DUI to secure a parliamentary majority of $61 \mathrm{MPs}$, they started to obstruct the work of the Parliament and did not allow for a peaceful transition of power (Popovikj 2017). The obstructions culminated with organised violent riots in the Macedonian Parliament in April 2017, after the new parliamentary majority appointed a new President of the Parliament. This event showed the destructive consequences of VMRO-DPMNE's mass abuse of state institutions which on one the hand enabled and, to certain extent, supported the riots, and on the other hand the outcomes of their nationalist rhetoric which had mobilised supporters to engage in such violence. The crisis ended with a power transition and the establishment of a

\footnotetext{
${ }^{7}$ As the agreement negotiations were held in the residence of the EU ambassador of North Macedonia in the Skopje suburb Przino, these agreements became known as the Przino agreements.
} 
new government formed by SDSM and DUI in May 2017, a month after the aforementioned violence in the Parliament.

\section{Institutional Aspects of Macedonian Illiberal Politics}

In the following pages, we will describe the crucial institutional policies and actions by which VMRO-DPMNE increased privileged access to state resources, media and law - and skewed the even playing field in their favour.

\section{Uneven Access to Resources}

Access to resources is uneven when ruling parties abuse their position and authority to take advantage of resources that are in serious disparity with the ones of the opposition. That might include partisan use of state resources, abuse of the state machinery (state buildings, vehicles, communication infrastructure) and public employees for campaign purposes as well as monopolised access to private sector finance (Levitsky and Way 2010, 10). In N. Macedonia the uneven access to resources was most evident in the differences in political party financing and campaign expenditures. During electoral campaigns VMRO-DPMNE reported considerably higher incomes and expenditures in comparison with the major party in opposition, the SDSM. For instance, in the 2013 local elections, OSCE/ODIHR's report noted that they spent five times more than the second closest competitor. Besides these high inter-party discrepancies, there were notable differences between VMRO-DPMNE's reported incomes and expenditures, as they were reporting higher expenditures than their reported incomes (State Electoral Commission 2014, 2016).

The released wiretapped conversations in 2015 indicated that VMRO-DPMNE's top party officials, led by the prime minister Nikola Gruevski, were directly involved in abuse of 
public institutions and resources. For illustration, in one wiretapped phone conversation the former Minister of Interior Gordana Jankulovska, describes how the premises of her ministry were used for party campaign purposes and how there was an entire party call-center within the ministry (Jordanovska 2015a). In another conversation, she explains that the police would obstruct the rally of the opposition by diverting the busses with opposition supporters to undergo a technical check. In other conversations, she and the Minister of Transport and Communications describe how they organized for ethnic Macedonians from Albania to get Macedonian citizenship and identity cards with Skopje addresses in order to vote for VMRODPMNE in the local 2013 elections (Jordanovska 2015a).

Clientelist employments and other benefits were used to mobilize political support. Top VMRO-DPMNE officials micromanaged their clientelist networks in order to maximize the benefits for their party (Petkovski and Nikolovski 2018). There are numerous wiretaps that confirmed the previous allegations that public sector employments had been largely controlled by the ruling party's bodies and officials. They organized and centralized the system of non-merit-based, party employments, making detailed lists of loyal party members that should be employed or promoted (Jordanovska 2015b). Party clients had to demonstrate not only their political loyalty, but to provide lists of 10 to 30 other voters who would certainly vote for the party. Besides this, clients were not only asked to be active during election campaign, but also to be involved in other initiatives of the party, including political rallies and 'spontaneous' protests and counter protests (Nikolovski 2013). Their presence was secured by the party's local branches which were responsible for mobilisation through direct communication with the people and registering the attendance at party events of each and every party member on their lists (Blazevska 2018). 
Moreover, election years were characterized by increased numbers of public sector employments (Cvetkovska 2013) and agricultural subsidies (Jankovska 2015), while there are examples in which even private companies mobilised their employees to vote for the incumbent political party (Delevska 2018). A good illustration is that although public sector employments were legally prohibited during election campaigns in order to prevent clientelist employments, during the local elections in 2013 there were numerous job advertisements for short-term employment in various public sector institutions (local self-government, education, health, etc.). Despite criticisms from experts who claimed that this was contrary to the law and would be used for clientelist electoral mobilisation, the government officials and the State Commission for Prevention of Corruption (SCPC) considered these employments as legal and in accordance with the needs of the respective institutions (Cvetkovska 2013).

\section{Uneven Access to Media}

Another aspect of VMRO-DPMNE's competitive authoritarian regime was uneven access to both state-owned and private media. During their rule, media freedom deteriorated, with the majority of media outlets being favourable towards the government and hostile towards the opposition (Freedom House 2017; Spasovska and Rusi 2015). While the state-owned radio and television traditionally supported incumbent political parties, most of the private media outlets were tied to political and business interests that influenced their editorial policies. According to a comparative media freedom ranking issued by Reporters Without Borders, in the last 10 years' Macedonian media freedom decreased 80 places, from 36th place in 2007 (out of 169 ranked countries) to 118th place in 2016. Problems with media freedom were noted in European Commission (EC) and US Department of State's reports. EC reports constantly raised concerns over 'government control over media' and 'scarcity of 
independent reporting and lack of accurate and objective information being made available through mainstream media to the public and a lack of informed public debate' (EC 2014, 2). Similarly, the US State Department reports $(2013,10)$ noted that ' $[\mathrm{t}] \mathrm{he}$ mainstream media rarely published views opposing the government' while only a limited number of media were independent and offered a variety of views.

Media loyalty was incentivised through well organised media-political clientelism (Micevski and Trpevska 2015) conducted primarily via extensive state-financed advertising and concentration of media ownership by several businessmen close to the government (Apostolov et al. 2015). The government was the top advertiser on private national TV stations, spending large amounts on buying loyalty and favourable treatment (Apostolov et al. 2015). According to the former president of the Association of Journalists of Macedonia Naser Selmani, annually the government was spending an equivalent of the annual budget of the Ministry of Defence (20 million euros) on advertising and media: 'These advertisements have nothing to do with the public interest of the citizens, these funds are used for buying and corrupting the media in order not to criticise governmental policies' (Dimovski 2014).

Furthermore, some of the most influential TVs and newspapers were already owned, or taken over, by businessmen close to the government. Such was the case with TV Sitel and TV Kanal 5 which were owned by junior coalition partners of VMRO-DPMNE, who won seats in the parliament mainly due to their media ownership which had guaranteed favourable news reporting. In addition, three of the most influential daily newspapers, Dnevnik, Vest and Utrinski, were taken over by an oligarch close to VMRO-DPMNE. These and other media outlets which were taken over experienced rapid change in their editorial policies, destroying 
their earlier professional standards and becoming biased and unprofessional (Dimovski 2014).

Finally, journalists were faced with numerous defamation cases issued by high-ranking ruling politicians which put them under additional pressure, as the rulings in these cases were usually in the politicians' favour (Risteska 2015). For instance, Jadranka Kostova, editor of the critical weekly magazine Focus was ordered to pay 15.000 euros in fines to VMRODPMNE's former Minister of Foreign Affairs Antonio Milososki, while the Journalists' Association in 2012 estimated that there were more than 300 lawsuits against journalist in the Macedonian courts, mostly brought by ruling politicians and connected businessmen (Marusic 2012a). As a consequence, journalists were under continuous pressure to report in a biased, pro-governmental manner and self-censor their work in order to keep their jobs (Apostolov et al. 2015; Dimovski 2014).

One of the biggest blows for Macedonian media freedom was the closure of N. Macedonia's first private, and most influential television station, A1 TV, in 2011. While characterised as 'the best and the worst of Macedonian media industry' (Ordanovski at al. 2012, 98 in Spasovska and Rusi 2015), A1 TV had had significant impact in the development of media pluralism and professional journalism. The television station was closed as an act of retaliation against its owner Velija Ramkovski who was initially close to Gruevski and VMRO-DPMNE but later, via A1 TV, had become a vocal critic of the government (Dimovski 2010; Ramet 2017). Ramkovski and number of his employees were charged and later sentenced for money laundering, tax evasion and criminal association (Spasovska and Rusi 2015). 


\section{Uneven Access to Law}

Uneven access to law is conducted through structured abuse of power and control of legal institutions (judiciaries, electoral commissions and other supposedly independent arbiters) that instead of working independently to protect the legal and constitutional order, work under influence and in favour of the incumbents. This affects political competition because unlike the opposition, incumbents enjoy privileged treatment and impunity that enables them to avoid or violate certain democratic and legal procedures without sanctions (Levitsky and Way 2010). This was the case in N. Macedonia, as the work of the judiciary and other oversight and law enforcement institutions were under strong political pressure that led to double standards favouring ruling party officials and disfavouring their political enemies. These problems were noted in number of domestic and foreign assessment documents where these issues were identified as key reasons for the country's backsliding in the process of EU accession and the spread of grand corruption and state capture (US Department of State 2011, 2012, 2013, 2014; EC 2015, 2016).

Political interference in the Macedonian judiciary became systemic during VMRO-DPMNE rule. It was mainly executed through control over the mechanisms for appointment, evaluation, promotion, discipline, and dismissal of judges, as these mechanisms were abused to reward the obedient cadres and punish those who did not conform with politically determined informal influence (Priebe 2015, 2017). Informal influence has been exercised primarily via the members of the Judicial Council, a body responsible for appointment, promotion and dismissal of judges. As can be heard in the wiretapped conversations, the decision making of the Judicial Council was directly coordinated between the highest party officials (Petkovski and Nikolovski 2018). Furthermore, there were abuses regarding the 
dismissal procedures, which were later characterised as unlawful by the European Court of Human Rights (ECHR). ${ }^{8}$ Political influence was also exercised through presidents of some of the key courts in the country. In 2017 the Ministry of Justice identified numerous irregularities related to abuse of the electronic system randomly assigning judges to cases (ACCMIS) in order to ensure that certain sensitive cases were allocated to specific judges (Akademik 2017). In 2015, when the Special Public Prosecutor started prosecuting high level officials form VMRO-DPMNE, the political loyalty of some court presidents became evident as they were abusing their formal competences by frequently reallocating judges to different court departments. These reallocations were made to assign loyal judges to sensitive judicial cases in which top VMRO-DPMNE officials were trialled (Dimovski 2017).

The control of the judiciary and law enforcement institutions was used to silence and discipline political opponents and public critics. Such was the arrest and conviction of the opposition politician Ljube Boskovski who left VMRO-DPMNE to form his own party United for Macedonia, becoming a very vocal critique of Gruevski. He was arrested one day after the parliamentary elections in 2011 in a staged case on grounds of illegal election campaign financing. His arrest was filmed and the video was later broadcasted on YouTube and on the web site of the Ministry of Interior. His case was noted by US State Department as a case of political imprisonment (US Department of State 2011). Later he was sentenced on five years and was released in 2016 (MKD.mk 2016). Similar targeted cases include those against the investigative journalist Tomislav Kezharovki (US Department of State 2013; Spasovska and Rusi 2015), against the president of the council of the opposition-led SkopjeCentar municipality Miroslav Shipovic (US Department of State 2013) and against the

\footnotetext{
${ }^{8}$ Mitrinovski v The Former Yugoslav Republic of Macedonia: ECHR 30 Apr 2015
} 
physician Dejan Stavric who lead the doctors' union strike against the Ministry of Health (US Department of State 2011).

Beside the political interference on the judiciary, the party had an extensive influence on other independent bodies such as the State Commission for Prevention of Corruption (SCPC). The commission was composed of seven members appointed by and loyal to the stable parliamentary majority of VMRO-DPMNE and DUI. While corruption was repetitively labelled as prevalent and serious problem, through the years there were cumulatively fewer cases processed and almost no actions against any incumbent political officials (Petkovski and Nikolovski 2018, 217). The European Commission has continuously criticised SCPC as passive, ineffective and prone to political influence (EC 2013, 2014, 2015, 2016). However, despite its passive role in chasing high-level government officials, during the 2013 elections the SCPC issued a public announcement about irregularity of the asset declaration of the opposition candidate for Mayor of the municipality of the Center, Andrej Zernovski. The timing of this action of SCPC, which was used to discredit the opposition candidate, coincided with the peak of the electoral contest in this key Skopje municipality and raised further questions about its impartiality (EC 2013). VMRO-DPMNE's control over the SCPC was also visible when, in 2015, one a member was appointed who had previously been a donor to the party. One year later he became president of the Commission (Jovanovska 2017).

In summary, policies and actions that increased VMRO-DPMNE's privileged access to state resources, media space and law, over time created an uneven playing field where parties in the opposition and critical voices were marginalised. This enabled continuous electoral success and broad legitimization of VMRO-DPMNE. In the next section we offer an 
overview of symbolic aspects of their illiberal politics which help us make better sense of the discursive mechanisms through which VMRO mobilized their support base among citizens.

\section{Symbolic Aspects of Macedonian Illiberal Politics}

In addition to the institutional capture discussed above, VMRO-DPMNE's continued electoral success can be best understood in reference to their coordinated attempts to monopolize public discourse and mobilize support through ethno-nationalist narrative. The symbolic aspects of their illiberal politics include the process of antiquization, anticommunist, anti-minority, conservative narratives, and concerted discrediting and smear campaigns against political opponents and civil society. Particularly after the Greek blocking of N. Macedonia's accession at the NATO summit in Bucharest in 2008, ethno-nationalist discourse has been reinforced as a main strategy for political mobilization and one of the main factors of the party's subsequent electoral success even in the light of failed economic promises and international stalemate (Andreassen 2011). Besides, VMRO-DPMNE under Gruevski also reinforced the widespread perception among impoverished citizens that SDSM's party cadres have largely benefited from the 'unlawful privatization' during the 1990s (Petkovski and Nikolovski 2018), at the same time managing to distance itself from the old VMRO-DPMNE's elites who themselves participated in the late stages of the privatization. These policies and practices were a complementary strategy for skewing the level playing field through delegitimization of political opponents and critics and directing the attention away from the glaring abuse of resources and law.

As part of its nationalist agenda, VMRO-DPMNE launched a set of 'identitarian policies based on the assumption that there is a direct link between today's ethnic Macedonians and 
Ancient Macedonians', popularly referred to as the process of 'antiquization' (Vangeli 2011, 13). This initially encompassed the renaming of the airport in Skopje as 'Alexander the Great', the Skopje stadium as 'National Arena Philip II', and the renaming of the main highway as 'Alexander of Macedonia'. The reconstruction of Skopje's city centre under the project 'Skopje 2014' aimed at glorifying the ancient history of Macedonians and served as a central symbol of the national renewal (Vangeli 2011; Keil 2018). As part of the project, dozens of monuments of historical figures were constructed and installed, among which the centre-stage is occupied by a massive statue of Alexander the Great. Several public buildings in neo-classical and baroque style were also built which, according to the architects, were aimed at obscuring the 'modernist constructions of the socialist period and the Ottoman-era architecture that indexes the city's Muslim heritage' (Graan 2013, 161). The reconstruction of national identity, while reinforcing ethnic divisions within the country, has also intensified the backlash from neighbouring Greece (Crowther 2017). Gruevski used this as an opportunity to consolidate his and VMRO-DPMNE's role as the ultimate guardians of the Macedonian identity from both external and internal threats (Günay and Dzihic 2016).

The government of Nikola Gruevski has launched a parallel yet complementary discourse of anti-communism. According to Spaskovska (2014) '[...] the socialist legacy has been progressively erased from the public space and existing historical narratives forged around the common anti-fascist struggle been played down and redefined [...]'. In this context a controversial Lustration Law was implemented which also encompassed the period of socialism up until 2006, the year when Gruevski's VMRO-DPMNE came to power. The Amended Law on Determining the Additional Condition for Performing Public Service (2011) extended its remit to apply to 'priests, journalists, NGO activists, lawyers and scientists', requiring them, in 2011-2012, to submit statements on their collaboration with 
secret services (Orlović 2013, 73). Though the Constitutional Court had, in a past ruling concerning the previous law on lustration, stated that such law can only apply for the period until 1991, the new law created by VMRO-DPMNE ignored this rule (Marusic 2012b).

The work of the Commission for the Verification of Facts [known as the Lustration Commission] was heavily criticized on the basis of alleged abuse of the law for discrediting and attacking political opponents and prominent civil society activists (Bohnet and Bojadzieva 2011). For example, the head of the Open Society Foundation in Macedonia and university professor Vladimir Milčin was publicly proclaimed as a collaborator with the communist security services on the basis of scarce evidence (Orlović 2013). Milčin, a vocal critic of Gruevski's policies, accused the head of the Lustration Commission of withholding documents that prove his innocence. He claimed that 'The goal of this lustration is not to settle the injustices of the past, but to tarnish people's reputation' (Marusic 2012b). The processes of lustration portrayed VMRO-DPMNE's political opponents as 'communist collaborators' harmful to the Macedonian interest.

The VMRO-led coalition through its extensive influence in the media led smear campaigns against civil society organisations, depicting them as being close to SDSM and serving the interests of foreign powers (Crowther 2017, 752; Keil 2018). Furthermore, the governing coalition enabled the 'proliferation of discriminatory discourses' against sexual minorities (Miškovska Kajevska 2018), reflecting the underlying conservative-religious consensus of VMRO-DPMNE and DUI (Spaskovska 2014). NGOs collaborating or being funded by the Open Society Foundation in Macedonia were under attack by media close to the government. For example, during civic protests against the building of a church on Skopje's main square, the earliest protests against VMRO-DPMNE's plan for the reconstruction of the city centre, 
media close to the government repeatedly tried to discredit the protest by pointing out the presence of members of the opposition party and employees of the Open Society Foundation (Nikolovski 2013, 23). Both the opposition party SDSM and the Open Society Foundation were associated with 'evil, conspiracy and treason' in the media (Nikolovski 2013, 24). This has been complemented by a wide-spread talk of 'de-Sorosization' of civil society and the emergence of patriotic NGOs and citizen initiatives for the protection of the name, tradition and identity of N. Macedonia (Jordanovska 2017; Petkovski and Nikolovski 2018). Many of the protests against the government's policies were faced with 'counter protests' organized by VMRO-DPMNE supporters. Citizens who opposed the government's policies were discouraged from joining public protests out of fear of being labelled as 'traitors' or 'Sorosoids'. Hence, SDSM had troubles mobilizing an effective opposition not only because of their limited institutional leverage but also because they were constructed as a symbol of all things-harmful for Macedonian national interests.

In summary, VMRO-DPMNE dominantly framed the public debate to mobilize and maintain its support base among ethnic Macedonians. By doing so, they met the demands for ethnonationalist, conservative and anti-communist discourse among the population. The successful monopolization of the public debate was made possible not only due to the privileged access to resources and media as discussed before but also the existence of loyal support base who believed and reproduced VMRO's narratives (see Schatz 2009).

\section{Discussion and Conclusion}

The paper focused on the institutional and symbolic aspects of the illiberal rule of the VMRO-DPMNE-led coalition and described the core characteristics of Macedonian illiberal politics in the period 2006-2017. The examples of abuse of political power presented 
demonstrate how the coalition led by VMRO-DPMNE, and their leader Nikola Gruevski, gained privileged access to resources, media and law that helped them to continuously win elections and legitimacy. While the creation of a an 'uneven playing field' through the abuse of state institutions and resources is a necessary factor accounting for their high political support and continuous electoral victories, we showed that symbolic illiberal policies also significantly contributed to VMRO-DPMNE's attainment and maintenance of power.

We identify different enabling circumstances of institutional and symbolic aspects of the illiberal politics in N. Macedonia described above. In line with Dolenec (2013) we argue that the institutional capture during VMRO-DPMNE is rooted in the post-communist power mutations enabled by SDSM during the regime change, which created a dominant executive, weak institutional checks and balances and advanced clientelist practices. The low economic development and living standard during the transition period acted as an enabling factor for clientelist politics. Subsequent parties in power 'perpetuated state capture and continued to subvert the rule of law' (Dolenec 2013, 48). In addition, one of the key enabling factors of illiberal tendencies in N. Macedonia is the implementation gap between rules in the books (formal laws) and how they are implemented in practice (informal practices). For instance, although N. Macedonia's legal framework aims in theory at ensuring equal opportunities, impartiality and meritocracy, there is plenty of evidence that Macedonian society, similarly to the rest of the Western Balkan region, largely operates in practice on the basis of nepotism, clientelism and corruption (Dehnert 2010; Bliznakovski, Gjuzelov and Popovikj 2017; Gordy, Cveticanin and Ledeneva eds. 2019). Questions of democratic accountability and fighting clientelism and corruption are constantly pushed into the background due to the 'ethnification of politics' (Dolenec 2013, 89). In these conditions of weak institutions, clientelism and the threat of multi-ethnic conflict, VMRO-DPMNE and DUI abused their 
formal authority and informally controlled state institutions and resources to maintain and maximise their political power. International actors such as EU and the US, due to the halted NATO and EU integration process were unable to constraint such developments (see Ilievski and Taleski 2009).

The symbolic illiberal politics of VMRO-DPMNE in the context of N. Macedonia emerged in relation to the entrenched feeling of threatened statehood and national identity by neighbouring Greece and Bulgaria and the internal multi-ethnic tensions underpinning the power-sharing arrangements. VMRO-DPMNE, as a right-wing nationalist party continuously maintained ethno-national questions on the domestic agenda. The failure to join NATO and start EU accession negotiations as result of the escalating name dispute with Greece hindered opportunities for economic development and increased the feeling of threatened statehood. These processes created the sentiment among ethnic Macedonians that their position has been threatened and their rights have been diminished. Hence, VMRO-DPMNE's symbolic policies for national reinvigoration resonated well with ethnic Macedonians and were perceived as 'taking back control' over the state. In addition, the traumatic memory of SDSM-dominated post-communist transition period and its resulting economic uncertainty for the citizens who lost their jobs and economic standard helped VMRO-DPMNE to legitimise their 'reform agenda' and discredit the opposition SDSM.

The interplay between institutional and symbolic aspects of illiberal politics is particularly important. These two aspects can exist separately and independently from each other, as well as co-exist together and reinforce each other. Namely, abuse of state resources to skew the even playing field does not necessarily imply involvement in discursive, symbolic elements of illiberal politics as described above. Also, monopolization of historical and societal 
narratives to maximise political power can be performed without drastic interference in the work of state institutions or abuse of state resources. The presented N. Macedonian case however shows the use of combination of strategies by governing elites to maximise institutional and symbolic (discursive) capture. For example, policies for privileged access to media supported the establishment of a dominant ethno-nationalist and conservative frames of Macedonian identity. Also, the smear campaigns against government critics and the control of the public debate directed public attention away from the abuse of state resources. The institutional and symbolic aspects of illiberal politics reinforced each other resulting in a strong push towards authoritarianism.

The conceptualisation of institutional and symbolic aspects of illiberal politics as two distinct but interconnected categories, is important beyond the present case of N. Macedonia, because it can be used to compare and examine not only the emergence of illiberal and authoritarian tendencies but also the maintenance of hybrid regimes in other cases of analysis. For instance, some regimes may be characterised only with institutional or symbolic aspects of illiberal politics and therefore be more or less susceptible to democratic backsliding. Whilst we find some overlapping enabling factors of institutional and symbolic politics in the case of N. Macedonia, it would be valuable to further examine under which conditions elites decide to use both strategies as oppose to one.

Furthermore, this framework can be used to compare illiberal tendencies within a single country across different periods of time. For instance, N. Macedonia's new government that came into power in 2017, based on the new coalition between SDSM and DUI, have dramatically changed the course of the previous VMRO-DPMNE and DUI coalition, primarily in regard to the symbolic elements of illiberal politics. Instead of taking advantage 
of the Greek vetoes and the name dispute, they reached a historic agreement with Greece and opened the doors for Macedonian integration into NATO and the EU under the new name of Republic of North Macedonia. They have also improved bilateral relations with Bulgaria and relaxed the interethnic tensions between Macedonians and Albanians. These actions have significantly transformed N. Macedonia's broader political context and restrained the major factors which enabled symbolic illiberal politics to thrive during VMRO-DPMNE's rule. In addition, there have been some improvements in the institutional aspects of governance: the previous governmental pressure on media has been relaxed, whilst state institutions have not (yet) been instrumentalized to generate unfair political competition. However, in the time of writing of this article, in spring 2019, the new political establishment have already started showing the first signs of some of the institutional aspects of illiberal politics elaborated above, primarily in regards to nepotism and clientelism, while there are still cases of nonuniversal and selective application of the law when interests of the incumbent parties or their officials are in question. Consequently, we expect institutional illiberal politics to continue to obstruct Macedonian democracy in the years to come.

\section{Declaration of interest statement}

There are no conflicts of interests to report. 


\section{References:}

Akademik. 2017. Констатирани бројни неправилности во АКМИС-системот, Akademik,

7 December. https://www.akademik.mk/konstatirani-brojni-nepravilnosti-vo-akmis-sistemot/.

Aleksovska, Marija. 2015. Trust in Changing Institutions: The Ohrid Framework Agreement and Institutional Trust in Macedonia. East European Quarterly 43 (1): 55-84.

Andreassen, Morten Dehli. 2011. 'If you don't Vote VMRO you're not Macedonian' A Study of Macedonian Identity and National Discourse in Skopje. MA thesis, University of Bergen.

Apostolov, Vlado, Tamara Chausidis, Dzvezdan Georgievski, and Santa Argirova. 2015. СТУДИЈА НА СЛУЧАЈ Медиуми, газди, новинари и работнички права. SSNM. http://www.merc.org.mk/Files/Write/Documents/01245/mk/Analiza_SSNM.pdf.

Bieber, Florian. 2011. Building Impossible States? State-Building Strategies and EU Membership in the Western Balkans. Europe-Asia Studies 63 (10): 1783-1802. doi:10.1080/09668136.2011.618679.

Bieber, Florian. 2018. Patterns of Competitive Authoritarianism in the Western Balkans. East European Politics 34 (3): 337-354. doi:10.1080/21599165.2018.1490272.

Bieber, Florian, and Irena Ristić. 2012. Constrained Democracy: The Consolidation of Democracy in Yugoslav Successor States. Southeastern Europe 36 (3): 373-397. doi:10.1163/18763332-03603005.

Bieber, Florian, and Magdalena Solska. 2018. Introduction. In Illiberal and Authoritarian Tendencies in Central, Southeastern And Eastern Europe, ed. Florian Bieber, Magdalena Solska and Dane Taleski, 11-20. Bern: Peter Lang CH.

Bieber, Florian, Magdalena Solska, and Dane Taleski. 2018. Illiberal and Authoritarian Tendencies in Central, Southeastern and Eastern Europe. Bern: Peter Lang CH.

Blazevska, Katerina. 2018. 27 Април - Ден на срам, крв и неподелени сендвичи. Prizma Birn, 26 April. https://prizma.mk/27-april-den-na-sram-krv-i-nepodeleni-sendvichi/.

Bliznakovski, Jovan, Borjan Gjuzelov, and Misha Popovikj. 2017. The Informal Life of Political Parties in the Western Balkan Societies. Institute for Democracy 'Societas Civilis'Skopje (IDSCS). http://formalinformal.eu/files/news/2017/Deliverables\%20and\%20Milestones\%202017/IDSCSInformal\%20Life\%20of\%20Political\%20Parties-Report-27092017.pdf.

Boduszyński, Mieczysław P. 2010. Regime Change in the Yugoslav Successor States, Divergent Paths Towards a New Europe. Baltimore: The Johns Hopkins University Press. 
Bogaards, Matthijs. 2018. De-Democratization in Hungary: Diffusely Defective Democracy. Democratization 25 (8): 1481-1499. doi:10.1080/13510347.2018.1485015.

Bohnet, Henri, and Daniela Bojadzieva. 2011. Coming to Terms with the Past in the Balkans The Lustration Process in Macedonia. KAS International Reports. https://www.kas.de/c/document_library/get_file?uuid=13c23ea7-0fa8-41f0-de9c6fc558dc3ba3\&groupId=252038.

Bustikova, Lenka, and Petra Guasti. 2017. The Illiberal Turn or Swerve in Central Europe? Politics and Governance 5 (4): 166. doi:10.17645/pag.v5i4.1156.

Casal Bértoa, Fernando, and Dane Taleski. 2015. Regulating Party Politics in the Western Balkans: The Legal Sources Of Party System Development in Macedonia. Democratization 23 (3): 545-567. doi:10.1080/13510347.2014.987664.

Casule, Kole. 2012. Macedonia Opposition Ejected from Parliament in Row. Reuters, 24 December. https://www.reuters.com/article/us-macedonia-protest/macedonia-oppositionejected-from-parliament-in-row-idUSBRE8BN0EX20121224.

Cianetti, Licia, James Dawson, and Seán Hanley. 2018. Rethinking 'Democratic Backsliding' in Central and Eastern Europe - Looking Beyond Hungary and Poland. East European Politics 34 (3): 243-256. doi:10.1080/21599165.2018.1491401.

Crowther, William. 2017. Ethnic Condominium and Illiberalism in Macedonia. East European Politics and Societies: And Cultures 31 (4): 739-761. doi:10.1177/0888325417716515.

Cvetkovska, Sashka. 2013. Анализа: Не запираат огласите за вработувања среде кампања. Nova TV, 30 March. https://novatv.mk/analizane-zapiraat-oglasite-zavrabotuvanja-srede-kampanja/.

Daskalovski, Zhidas. 2004. Democratic Consolidation and the 'Stateness' Problem: The Case of Macedonia. Global Review of Ethnopolitics 3 (2): 52-66. doi:10.1080/14718800408405165.

Dehnert, Stefan. 2010. Elections and Conflict in Macedonia Country Analysis. FriedrichEbert Stiftung. https://library.fes.de/pdf-files/iez/07523-b.pdf.

Delevska, S.K. 2018. Не вртете вие, вртат моиве од ОРКА - Му вика Орце Камчев на Јанакоевски во бомбите за изборите 2013. SDK.MK, 30 October.

https://sdk.mk/index.php/makedonija/ne-vrtete-vie-vrtat-moive-od-orka-mu-vika-ortsekamchev-na-janakieski-vo-bombite-za-izborite-2013/.

Dimovski, Sase. 2010. Velija Ramkovski - Shady Tycoon or Media Hero? Balkaninsight, 2 December. http://www.balkaninsight.com/en/article/velija-ramkovski-shady-tycoon-ormedia-hero. 
Dimovski, Sashe. 2014. Медиумските донации за политичките партии и сопственичката структура потенцијален извор на корупција во македонските медиуми.

http://mediapedia.tamijov.webfactional.com/media/dokumenti/Korupcija-mediumi-final.pdf.

Dimovski, Sase 2017. Скопска единица расчисти со побунениците против Панчевски, ги прати во прекршоци. Сведок, 21 February.

http://www.svedok.org.mk/mk/record.php?id=718.

Dolenec, Danijela. 2013. Democratic Institutions and Authoritarian Rule in Southeast Europe. Colchester: European Consortium for Political Research.

European Commission. 2016. The former Yugoslav Republic of Macedonia 2016 Report. https://ec.europa.eu/neighbourhood-

enlargement/sites/near/files/pdf/key_documents/2016/20161109_report_the_former_yugosla v_republic_of_macedonia.pdf.

European Commission. 2015. The former Yugoslav Republic of Macedonia 2015 Progress Report. https://ec.europa.eu/neighbourhood-

enlargement/sites/near/files/pdf/key_documents/2015/20151110_report_the_former_yugosla v_republic_of_macedonia.pdf.

European Commission. 2014. The former Yugoslav Republic of Macedonia 2014 Progress Report. https://ec.europa.eu/neighbourhood-

enlargement/sites/near/files/pdf/key documents/2014/20141008-the-former-yugoslavrepublic-of-macedonia-progress-report_en.pdf.

European Commission. 2013. The former Yugoslav Republic of Macedonia 2013 Progress Report. https://ec.europa.eu/neighbourhood-

enlargement/sites/near/files/pdf/key_documents/2013/package/mk_rapport_2013.pdf.

Freedom House. 2017. Freedom in The World 2017 Macedonia Profile.

https://freedomhouse.org/report/freedom-world/2017/macedonia.

Gordy, Eric, Predrag Cveticanin, and Alena Ledeneva, eds. Forthcoming. The Gap Between Rules and Practices: Informality in South-East Europe. London: UCL Press, FRINGE Series.

Graan, Andrew. 2013. Counterfeiting the Nation? Skopje 2014 and the Politics of Nation Branding in Macedonia. Cultural Anthropology 28 (1): 161-179. doi:10.1111/j.15481360.2012.01179.x.

Greskovits, Béla. 2015. The Hollowing and Backsliding of Democracy in East Central Europe. Global Policy 6: 28-37. doi:10.1111/1758-5899.12225.

Günay, Cengiz, and Vedran Dzihic. 2016. Decoding the Authoritarian Code: Exercising 'Legitimate' Power Politics Through the Ruling Parties in Turkey, Macedonia and Serbia. Southeast European And Black Sea Studies 16 (4): 529-549. doi:10.1080/14683857.2016.1242872. 
Ilievski, Zoran, and Dane Taleski. 2009. Was the EU's Role in Conflict Management in Macedonia a Success? Ethnopolitics 8 (3-4): 355-367. doi:10.1080/17449050903086955.

Ilievski, Zoran. 2007. Ethnic Mobilization of Macedonia. Eurac Research. http://www.eurac.edu/en/research/autonomies/minrig/Documents/Mirico/Macedonia\%20Rep ort.pdf.

Jankovska, Sonja. 2015. Субвенции во земјоделството - Реална помош или промашена политика?. Prizma Birn, 15 June. https://prizma.mk/subventsii-vo-zemjodelstvoto-realnapomosh-ili-promashena-politika/.

Jordanovska, Meri. 2017. Се множат патриотските невладини организации. Prizma Birn, $21 \mathrm{March}$. https://prizma.mk/se-mnozhat-patriotskite-nevladini-organizatsii/.

Jordanovska, Meri. 2015а. Седмата бомба на СДСМ ги откри изборните манипулации. Prizma Birn, 6 March. https://prizma.mk/sedmata-bomba-na-sdsm-gi-otkri-izbornitemanipulatsii/.

Jordanovska, Meri. 2015b. Партиска агенција за вработување. Prizma Birn, 14 April. https://prizma.mk/partiska-agentsija-za-vrabotuvane/.

Jovanovska, Maja. 2017. Игор Тантуровски реизбран за претседател на Антикорупциска Комисија. Nova TV, 13 April. https://novatv.mk/igor-tanturovski-reizbran-za-pretsedatel-naantikoruptsiska-komisija/.

Kapidžić, Damir. Forthcoming. The Rise of Illiberal Politics in Southeast Europe. Southeast European and Black Sea Studies.

Keil, Soeren. 2018. The Business of State Capture and the Rise of Authoritarianism in Kosovo, Macedonia, Montenegro And Serbia. Southeastern Europe 42: 59-82.

Kostovicova, Denisa, and Vesna Bojicić-Dželilović. 2006. Europeanizing the Balkans: Rethinking the Post-Communist and Post-Conflict Transition. Ethnopolitics 5 (3): 223-241. doi:10.1080/17449050600911091.

Levitsky, Steven, and Lucan A. Way. 2010. Competitive Authoritarianism: Hybrid Regimes After the Cold War. Cambridge University Press.

Marusic, Sinisa Jakov. 2011. Macedonian Opposition Say Boycott Goes On. Balkaninsight, 10 February. http://www.balkaninsight.com/en/article/macedonian-opposition-continuesboycott.

Marusic, Sinisa Jakov. 2012a. Macedonian Journalists Cry Foul Over Libel Reform. Balkaninsight, 15 June. https://balkaninsight.com/2012/06/15/macedonian-journalists-cryfoul-over-libel-reform/. 
Marusic, Sinisa Jakov. 2012b. Macedonian NGO Chief To Sue Lustration Body. Balkan Tranistional Justice, 13 August. https://balkaninsight.com/2012/08/13/macedonian-ngochief-to-sue-lustration-body/.

Marusic, Sinisa Jakov. 2013. Last-Ditch Efforts Made to Solve Macedonia Crisis.

Balkaninsight, 28 February. http://www.balkaninsight.com/en/article/last-ditch-efforts-tosolve-macedonian-crisis.

Marusic, Sinisa Jakov. 2014. Macedonia Opposition Toughens Line On Poll Fraud. 2 May, Balkaninsight, 2 May. http://www.balkaninsight.com/en/article/opposition-cements-defianceagainst-electoral-fraud.

Marusic, Sinisa Jakov. 2016a. Thirteenth Night of Protests Ends in Macedonia.

Balkaninsight, 26 April. http://www.balkaninsight.com/en/article/thirteenth-night-of-protestsends-in-macedonia-04-26-2016.

Marusic, Sinisa Jakov. 2016b. Macedonia's SJO Says Secret Police Ran Illegal Wiretapping. Balkaninsight, 18 November. http://www.balkaninsight.com/en/article/macedonia-s-sjo-sayssecret-police-ran-illegal-wiretapping-11-18-2016\#sthash.IIVT8JS9.dpuf.

Micevski, Igor, and Snezana Trpevska. 2015. What the Macedonian Phone-Tapping Scandal Tells Us About Clientelism in the Media. International Journal of Digital Television 6 (3): 319-326. doi:10.1386/jdtv.6.3.319_1.

Miškovska Kajevska, Ana. 2018. A Foe of Democracy, Gender and Sexual Equality in Macedonia: The Worrisome Role of The Party VMRO-DPMNE. Politics And Governance 6 (3): 55. doi:10.17645/pag.v6i3.1415.

Mitrinovski v The Former Yugoslav Republic of Macedonia: ECHR 30 Apr 2015. 2017. ECHR.

MKD.mk. 2016. Љубе Бошкоски пуштен од затвор, 2016. MKD.mk, 3 June. https://www.mkd.mk/makedonija/politika/ljube-boshkoski-pushten-od-zatvor.

Nikolovski, Dimitar. 2013. Traitors Hirelings and Sandwich-Protesters: Civil Activism in Macedonian Public Discourse. Skopje: Foundation Open Society - Macedonia. http://eurothink.mk/gridfs/data/id/5820fe8efffc7468d62a9bc7.

Offe, Claus. 2004. Capitalism by Democratic Design?: Democratic Theory Facing The Triple Transition in East Central Europe. Social Research: An International Quarterly 71 (3): 501528.

Orlović, Sandra. 2013. Transitional Justice in Post-Yugoslav Countries: Report For 20102011. Belgrade: Humanitarian Law Center. http://recom.link/wpcontent/uploads/2014/12/Transitional-Justice-in-Post-Yugoslav-countries-2010-2011.pdf. 
OSCE/ODIHR. 2006. The Former Yugoslav Republic of Macedonia Parliamentary Elections OSCE/ODIHR Election Observation Mission Final Report. Warsaw: Office for Democratic Institutions and Human Rights.

https://www.osce.org/odihr/elections/fyrom/20630?download=true.

OSCE/ODIHR. 2008. The Former Yugoslav Republic of Macedonia Early Parliamentary Elections OSCE/ODIHR Election Observation Mission Final Report. Warsaw. https://www.osce.org/odihr/elections/fyrom/33152?download=true.

OSCE/ODIHR. 2009. The Former Yugoslav Republic of Macedonia Presidential and Municipal Elections OSCE/ODIHR Election Observation Mission Final Report. Warsaw. https://www.osce.org/odihr/elections/fyrom/37851?download=true.

OSCE/ODIHR. 2011. The Former Yugoslav Republic of Macedonia Early Parliamentary Elections 5 June 2011 OSCE/ODIHR Election Observation Mission Final Report. Warsaw. https://www.osce.org/odihr/elections/FYROM/83666?download=true.

OSCE/ODIHR. 2013. The Former Yugoslav Republic of Macedonia Municipal Elections 24 March And 7 April 2013 OSCE/ODIHR Election Observation Mission Final Report. Warsaw. https://www.osce.org/odihr/elections/103411?download=true.

OSCE/ODIHR. 2014. The Former Yugoslav Republic of Macedonia Presidential and Early Parliamentary Elections 13 And 27 April 2014 OSCE/ODIHR Election Observation Mission Final Report. Warsaw. https://www.osce.org/odihr/elections/fyrom/121306?download=true.

OSCE/ODIHR. 2016. The Former Yugoslav Republic of Macedonia Early Parliamentary Elections 11 December 2016 OSCE/ODIHR Election Observation Mission Final Report. Warsaw. https://www.osce.org/odihr/elections/fyrom/302136?download=true.

Petkovski, Ljupco, and Dimitar Nikolovski. 2018. Macedonia: Illiberal Democracy or Outright Authoritarianism?. In Illiberal and Authoritarian Tendencies in Central, Southeastern and Eastern Europe, 205-224. Bern, Switzerland: Peter Lang CH.

Popovikj, Misha. 2017. Violence in The Macedonian Parliament: What Happened and How Should the EU Respond?. Blog. LSE EUROPP - European Politics and Policy, 28 April. http://blogs.lse.ac.uk/europpblog/2017/04/28/violence-macedonian-parliament-whathappened-eu-response/.

Priebe, Reinhard. 2015. The former Yugoslav Republic of Macedonia: Recommendations of the Senior Experts' Group on Systemic Rule of Law Issues Relating to the Communications Interception Revealed in Spring 2015. Brussels. https://ec.europa.eu/neighbourhoodenlargement/sites/near/files/news_corner/news/newsfiles/20150619_recommendations_of_the_senior_experts_group.pdf.

Priebe, Reinhart. 2017. The former Yugoslav Republic of Macedonia: Assessment and Recommendations of The Senior Experts' Group on Systemic Rule of Law Issues 2017. European Commission. https://ec.europa.eu/neighbourhood- 
enlargement/sites/near/files/2017.09.14_seg_report_on_systemic_rol_issues_for_publication. pdf.

Ramet, Sabrina P. 2017. Macedonia's Post-Yugoslav Reality: Corruption, Wiretapping, and Stolen Elections. In Building Democracy in the Yugoslav Successor States: Accomplishments, Setbacks, And Challenges Since 1990, 287-320. Cambridge: Cambridge University Press.

Risteska, Marija. 2015. Nations in Transit 2015 Macedonia. Freedom House. https://freedomhouse.org/sites/default/files/NIT_2015_Macedonia.pdf.

Schatz, Edward. 2009. The Soft Authoritarian Tool Kit: Agenda-Setting Power in Kazakhstan and Kyrgyzstan. Comparative Politics 41 (2): 203-222. doi:10.5129/001041509x12911362972034.

Spaskovska, Ljubica. 2014. From Feudal Socialism to Feudal Democracy - The Trials and Tribulations of the Former Yugoslav Republic of Macedonia. Blog. Opendemocracy. https://www.opendemocracy.net/can-europe-make-it/ljubica-spaskovska/from-feudalsocialism-to-feudal-democracy-trials-and-tribulati.

Spasovska, Katerina, and Iso Rusi. 2015. From 'Chaos' To 'Order': The Transition of the Media in Macedonia from 1989 To 2014. Southeastern Europe 39.

State Electoral Commission. 2014. http://old.sec.mk/arhiva-rezultati/izbori2014/predvremeni-parlam-2014/322-fin-izv-pretvremeni.

State Electoral Commission. 2016. http://www.sec.mk/predvremeni-izbori-za-pratenici$2016 /$.

US Department of State. 2011. Country Reports on Human Rights Practices for 2011 Macedonia. Bureau of Democracy, Human Rights and Labor. https://www.state.gov/documents/organization/186589.pdf.

US Department of State. 2012. Country Reports on Human Rights Practices for 2012 Macedonia. Bureau of Democracy, Human Rights and Labor. https://www.state.gov/documents/organization/204523.pdf.

US Department of State. 2013. Country Reports on Human Rights Practices for 2013 Macedonia. Bureau of Democracy, Human Rights and Labor. https://www.state.gov/documents/organization/220516.pdf.

US Department of State. 2014. Country Reports on Human Rights Practices for 2014 Macedonia. Bureau of Democracy, Human Rights and Labor. https://www.state.gov/documents/organization/236762.pdf.

van Biezen, Ingrid, Peter Mair, and Thomas Poguntke. 2011. Going, Going,...Gone? The Decline of Party Membership in Contemporary Europe. European Journal of Political Research 51 (1): 24-56. doi:10.1111/j.1475-6765.2011.01995.x. 
Vangeli, Anastas. 2011. Nation-Building Ancient Macedonian Style: The Origins and the Effects of the So-Called Antiquization in Macedonia. Nationalities Papers 39 (1): 13-32. doi:10.1080/00905992.2010.532775 
Table 1. General conclusions of OSCE/ODIHR Election Observation Mission Reports

\begin{tabular}{|c|c|}
\hline $\begin{array}{l}\text { Parliamentary } \\
\text { elections } 2006\end{array}$ & $\begin{array}{l}\text { '[E]elections largely met OSCE commitments for democratic elections, } \\
\text { instances of violence and intimidation during the first half of the campaign, } \\
\text { and a number of cases of serious irregularities on election day, cast a } \\
\text { shadow over an otherwise generally well-administered election held in a } \\
\text { competitive environment.' (OSCE/ODIHR 2006, 1) }\end{array}$ \\
\hline $\begin{array}{l}\text { Early } \\
\text { Parliamentary } \\
\text { elections } 2008\end{array}$ & $\begin{array}{l}\text { 'In most of the country the elections were procedurally well administered. } \\
\text { However, expectations of progress were not realized because of a failure by } \\
\text { some election stakeholders and relevant authorities to prevent violent acts } \\
\text { in predominantly ethnic Albanian areas, including limited and selective } \\
\text { enforcement of laws.' (OSCE/ODIHR 2008, 1) }\end{array}$ \\
\hline $\begin{array}{l}\text { Presidential and } \\
\text { Municipal } \\
\text { elections } 2009\end{array}$ & $\begin{array}{l}\text { '[E]lections were administered in a professional and transparent manner. } \\
\text { Some problems were evident, such as allegations of intimidation of voters } \\
\text { in the pre-election periods.' (OSCE/ODIHR } 2009,1)\end{array}$ \\
\hline $\begin{array}{l}\text { Early } \\
\text { Parliamentary } \\
\text { elections } 2011\end{array}$ & $\begin{array}{l}\text { [E]lections were competitive, transparent, and well-administered } \\
\text { throughout the country, although certain aspects require attention. These } \\
\text { include measures to ensure an adequate separation of state and party } \\
\text { structures, a thorough voter list audit, and clarification of certain } \\
\text { provisions in the Electoral Code. (OSCE/ODIHR: } 2011,1 \text { ) }\end{array}$ \\
\hline $\begin{array}{l}\text { Local elections } \\
2013\end{array}$ & $\begin{array}{l}\text { '[E]lections were efficiently administered and highly competitive. } \\
\text { However, partisan media coverage and a blurring of state and party } \\
\text { activities did not provide a level playing field for candidates to contest } \\
\text { the elections. (OSCE/ODIHR: } 2013,1 \text { ) }\end{array}$ \\
\hline $\begin{array}{l}\text { Presidential and } \\
\text { early } \\
\text { parliamentary } \\
\text { elections } 2014\end{array}$ & $\begin{array}{l}\text { '[E]lections were efficiently administered, including on election day. } \\
\text { Candidates were able to campaign without obstruction and freedoms of } \\
\text { assembly and association were respected. However, the elements of the } \\
\text { campaign indicated an inadequate separation between party and state } \\
\text { activities (...) Allegations of voter intimidation persisted throughout the } \\
\text { campaign...' (OSCE/ODIHR: } 2014: 1 \text { ) }\end{array}$ \\
\hline $\begin{array}{l}\text { Early } \\
\text { Parliamentary } \\
\text { elections } 2016\end{array}$ & $\begin{array}{l}\text { 'The parties were generally able to campaign freely, and fundamental } \\
\text { freedoms of association, assembly and expression were respected. (...) } \\
\text { Allegations of voter intimidation, coercion, pressure on civil servants, }\end{array}$ \\
\hline
\end{tabular}




\begin{tabular}{|l|l|}
\hline vote-buying, and the misuse of administrative resources persisted \\
through the campaign. (...) Such actions raised concerns about voters' \\
ability to cast their vote free of fear of retribution...' (OSCE/ODIHR: 2016: \\
1)
\end{tabular}

